\title{
Динамика этнокультурной политики в России, Казахстане и Украине: отложенная «национализация»?'
}

\author{
В.С. МАЛАХОВ*, А.Г. ОСИПОВ**
}

\begin{abstract}
*Владимир Сергеевич Малахов - доктор политических наук, профессор, директор Центра теоретической и прикладной политологии, Институт общественных наук Российской академии народного хозяйства и государственной службы (РАНХиГС); преподаватель Московской Высшей Школы Социальных и Экономических наук (МВШСЭН). Адрес: 119571, Москва, пр-т Вернадского, д. 82, стр. 1. E-mail: vmalachov@yandex.ru **Александр Геннадьевич Осипов - кандидат исторических наук, член Совета Международного центра изучения этнического и языкового разнообразия (International Centre for Ethnic and Linguistic Diversity Studies; Прага). Адрес: Korunní 2569/108, 10100 Praha 10, Czechia. E-mail: aosipov1@gmail.com
\end{abstract}

Цитирование: Малахов В.С., Осипов А.Г. (2021) Динамика этнокультурной политики в России, Казахстане и Украине: отложенная «национализация»? // Мир России. Т. 30. № 2. C. 26-47. DOI: 10.17323/1811-038X-2021-30-2-26-47

Статья посвящена факторам и динамике этнокультурной политики в трех крупнейших постсоветских странах: России, Казахстане и Украине. Авторы анализируют, почему ожидания того, что наџиестроительство в постсоветских странах примет репрессивньй характер, в целом не оправдывались долгое время после распада СССР, но отчасти материализуются в последние годы. В середине 1990-х годов Р. Брубейкер полагал, что новые независимые государства будут проводить последовательную политику восстановления социальных и культурных позищий своих основных этнических наций в ущерб меньиинствам. Однако реальные прочессы развивались по иному сценарию, в основе которого лежала стратегическая амбивалентность - идеологический эклектизм и правовая неопределенность в деятельности правительств, сочетавшиеся с отсутствием массовой мобилизачии и массовых протестов. Авторский анализ основывается на рассмотрении институционального дизайна этнокультурной политики. По мысли авторов, происходивщее в постсоветских странах объясняется советским институциональным наследием и может описываться как инерционный сиенарий. Авторы также отвечают на вопрос, почему в последние годы в России и Украине правящие круги сделали выбор в пользу радикальной гомогенизирующей

1 Статья подготовлена в рамках гранта, предоставленного Министерством науки и высшего образования Российской Федерации (соглашение № 075-15-2020-908). 
политики. Инерциионный сцеенарий основан на подвижном равновесии и потому подвержен влиянию внешних возмущений, таких как внешнеполитические конфликты.

Ключевые слова: этнокультурная политика, культурное разнообразие, национальное государство, «национализирующиеся государства», национализм, Россия, Украина, Казахстан

\section{Введение}

Согласно распространенной точке зрения, многоэтничность является вызовом для большинства постсоветских стран и потенциально создает угрозы их целостности, стабильности и управляемости. В обсуждениях этих проблем особое место занимает концепция «национализирующегося государства», которую в середине 1990-х гг. предложил Роджерс Брубейкер [Brubaker 1996]. Эта теоретическая модель описывает государственную политику, призванную обеспечить доминирующее положение основной, или «ядерной» (core), этнической нации в осуществлении власти в общественной жизни и возможные реакции на нее. Ожидания, что подобная политика будет последовательно проводиться в странах бывшего СССР и вызовет масштабные конфликты, в целом не оправдались. Однако в последние годы перемены в двух крупнейших постсоветских странах - России и Украине вынуждают вспомнить термин «национализация».

Из этих наблюдений и родился замысел настоящей статьи. Мы хотим понять, что определяет динамику этнокультурной политики (или, в привычном для советской и постсоветской бюрократии словоупотреблении, «национальной политики») в странах бывшего СССР. Что лежит в основе ее дизайна и содержания? Почему в одних странах в те или иные периоды времени правящие элиты стремятся сохранять статус-кво, а в других инициируют радикальные перемены? В какой мере управленческие решения в данной сфере были детерминированы советским наследием?

В качестве эмпирических казусов мы рассматриваем три крупнейшие постсоветские страны: Россию, Казахстан и Украину.

\section{«Национализация» как несостоявшийся прогноз}

Согласно теории Роджерса Брубейкера, «национализирующиеся государства» это страны, правящие элиты которых рассматривают их как «недогосударства», как организационные вместилища, которые еще предстоит наполнить национальным содержанием. При этом «национальное» интерпретируется как этническое, а «государство» трактуется как принадлежность определенной (этно)нации, служащее ее интересам (of and for an ethnic group).

Выдвигая свою концепцию в середине 1990-х гг., Р. Брубейкер предполагал, что развитие ситуации в постсоветских странах пойдет по следующему сценарию: поскольку национализм правящих элит в новых государствах представляет собой политический проект, то его реализация будет зависеть от диспозиций 
на политическом поле. Последнее можно изобразить в виде своеобразного треугольника: его вершинами, наряду с «национализирующимся государством», выступают национальные (этнические) меньшинства и соседние страны, являющиеся для этих меньшинств внешней этнической родиной. Деятельность правительства внутри конкретной страны будет направлена на создание преимуществ для «основной» этнонации (ввиду того что государство воспринимается как ее «собственность») и на маргинализацию меньшинств и даже их исключение из общественной жизни. И если русские - как правило, крупнейшее этническое меньшинство в постсоветских республиках - из политии де-факто исключены ${ }^{2}$ (даже при гарантиях индивидуальных прав), они будут стремиться к восстановлению своего публичного статуса и оказывать организованное сопротивление, которое, вероятно, будет поддержано Россией.

Последующие десятилетия, однако, не подтвердили этот прогноз: государства-наследники СССР в основном проводили достаточно сбалансированную политику ${ }^{3}$. Люди, которых можно условно определить как «русских», выбрали адаптацию к новым условиям или эмиграцию, а Россия, несмотря на громкую официальную риторику защиты соотечественников, действовала в русле международного права [Зевелев 2008; Shevel 2010].

Почему мы уделяем такое внимание концепции Р. Брубейкера, хотя она (по крайней мере, до середины 2010-х гг.) в целом не выдерживала эмпирической проверки, и сам автор от нее фактически отказался [Brubaker 2011]? Это теоретическое построение интересно (помимо введения в оборот удобного термина «национализация») рядом произвольных допущений, которые разделяли и разделяют многие исследователи. Мы имеем в виду не всегда осознанное или плохо отрефлексированное стремление усматривать в изучаемой реальности коллективные агентства с заранее заданными интересами, целями и мотивациями. Для Р. Брубейкера «национализация» - это осознанная стратегия, проект, в основе которого лежит априорное стремление правящих элит и государственного аппарата следовать этнонационалистическим мотивам. В свою очередь «государства», «элиты», «меньшинства», «русские», по сути, выступают как сущности, а не категории описания, как акторы, движимые этнонационалистическим видением мира. Дополнительную живучесть подобному подходу придает широко вошедшее в моду понятие «идентичности». Ничего не объясняя само по себе, оно изначально риторически конструирует единого социального актора, якобы связанного общим социокультурным «багажом» непонятной природы и движимого общими интересами и мотивациями.

Наша гипотеза основана на том, что такие аналитически конструируемые общности, как «элиты», «правящие круги», «народы» и «меньшинства» принципиально неоднородны с точки зрения мотиваций и интересов, а составляющие их индивиды склонны к оппортунистическому поведению. Отсюда проистекает задача проанализировать институциональные рамки формирования представлений, интересов и мотиваций, а также обстоятельства, заставляющие людей корректировать свое поведение. Мы пытаемся понять, чем в этой связи похожи и чем отличаются друг от друга постсоветские государства.

\footnotetext{
2 А в Эстонии и Латвии они в значительной степени оказались исключены и де-юре.

3 За исключением Эстонии и Латвии, которые по многим параметрам могут рассматриваться как воплощение модели «национализирующихся государств».
} 


\section{Советское наследие}

Институционализация этничности в СССР проявлялась в двух основных формax: делении политического пространства и делении населения [Slezkine 1994; Suny 1993; Brubaker 1996]. Во-первых, этнический принцип лежал в основе территориального устройства: союзные республики и национально-территориальные образования разного уровня рассматривались как квазисобственность того или иного этнического сообщества (именовавшегося «нацией» или «народностью»). Во-вторых, этническая принадлежность фиксировалась в паспортах и других документах учета населения. Факт отнесенности к той или иной этнической группе мог оказаться определяющим в доступе индивидов к социальным ресурсам и власти, в силу чего этничность воспринималась ими как экзистенциально важная характеристика [Martin 2001, pp. 442-451; Tishkov 1997, pp. 24-43].

В советской идеологии причудливо совмещались конфликтующие между собой представления об организации общества. Среди них присутствовали, с одной стороны, национализм (поскольку власти исходили из представлений об этнической основе государственности), а с другой стороны, поддержка полиэтничности и полилингвизма в обществе; с одной стороны, декларировалась защита прав граждан, с другой стороны, государство подчеркивало приверженность концепции групповых прав. В официальной риторике позднесоветского времени утверждалось равенство граждан независимо от их этнической принадлежности, однако оно уравновешивалось такими «фигурами», как самоопределение и суверенитет этнических наций; более того, до сих пор остается непонятным, как предполагалось реализовывать равенство индивидов в условиях символической иерархии этнических групп - когда одни группы, вроде бы, «равнее» других. Эта система характеризовалась разрывом между риторикой власти и ее действиями. Официальные тропы, основанные на идеях групповых прав, не означали, что допускается какая-либо несанкционированная, тем более коллективная активность на этнической почве. Установки на многонациональность и многоязычие сочетались с гомогенизирующей политикой, а языки со второй половины 1930-х гг. (за отдельными исключениями) не имели признанного законом статуса.

Советское наследие воспроизводится и в новых независимых государствах. Во-первых, постсоветские страны унаследовали от своего предшественника эклектизм в том, что касается концептуализации национальной политики. В законодательствах сосуществуют те же конфликтующие принципы, а положения официальных актов, принимаемых в сфере этнокультурного регулирования, сформулированы настолько обтекаемо, что позволяют свободно их интерпретировать. Во-вторых, сохраняется формальная преемственность: в некоторых постсоветских странах действует или до самого недавнего времени действовало (с изменениями) советское законодательство о языках ${ }^{4}$. Законы о меньшинствах, там, где они есть, хотя и были приняты уже после обретения независимости, разрабатывались еще при коммунистическом режиме. Структура и функции органов власти, отвечающих за управление этнокультурной неоднородностью (национальную политику), в основном были определены в 1990-1991 гг., т. е. на излете советской эпохи

4 В Беларуси, Молдове, России и Украине. 
[Беспамятных и др. 2014]. В-третьих, как и в советское время, наряду с писаными формальными - правилами и нормами на практике до сих пор действуют и неформальные [Беспамятных и др. 2014; Isaacs, Polese 2015]. Благодаря расплывчатости языка правовых актов, а также разрыву между законодательными положениями и правоприменением у профессиональных управленцев возникает широкое пространство маневра: они не просто имеют возможность интерпретировать (или избирательно применять) те или иные положения закона в зависимости от конъюнктуры, в алгоритм их деятельности уже заложено отсутствие определенности. Ниже, заимствуя выражение Доннаха О’Бехена и Роба Кевлиана [Ó Beacháin, Kevlihan 2013], мы будем называть эту ситуацию стратегической амбивалентностью (strategic ambiguity).

Выше мы обозначили общие идейные и организационные рамки, однако остается вопрос, в чем состоит специфика процессов и их результатов в отдельных странах.

\section{Россия}

И до, и после распада СССР исследователи и политики не воспринимали Российскую Федерацию как полноценную союзную республику на русской этнической основе. Само российское руководство на рубеже 1980-1990-х гг. использовало эклектичную и противоречивую риторику, то противопоставляя Россию Советскому Союзу, то рассматривая ее в качестве страны-продолжателя, при этом на официальном уровне вопросы о роли и месте этнических русских замалчивались. На первый план всегда выходила специфика России, связанная с феноменом так называемого этнического федерализма. И хотя в начале $1990-$ х гг. звучали голоса в поддержку ликвидации автономий и «национализации», у центра не было ни ресурсов, ни желания реализовывать этот сценарий.

Другая принципиальная особенность российского случая по сравнению с прочими постсоветскими странами заключается в наличии в России широкого социокультурного консенсуса относительно бесспорного доминирования русского языка и тесно связанных с ним образцов городской культуры. Нельзя сказать, что подобная урбанизированная культура не сложилась в других частях бывшего советского пространства, включая Казахстан и Украину, но там после распада СССР началось оспаривание ее доминирования, выразившееся прежде всего в языковой политике, нацеленной на расширение публичного использования национального языка и, соответственно, сужение использования русского.

В начале 1990-х гг. Россия столкнулась с центробежными тенденциями на фоне относительной слабости центральной власти. Федеральный центр обнаружил себя перед необходимостью торга с региональными элитами. В случаях, когда этот торг накладывался на этнические различия, он приобретал подчас крайне политизированный характер [Паин 2004]. Впоследствии возможности центра существенно возросли, и на этом фоне выявилось заметное снижение значимости этнического фактора в российской внутренней политике [Giuliano, Gorenburg 2012]. На протяжении двух последних десятилетий мы стали свидетелями рецентрализации власти: Москва отняла у регионов полномочия, приобретенные ими де-юре или де-факто в 1990-е; также произошла унификация административного пространства. 
Унификация образовательной политики оказалась долгой и поэтапной [Zamyatin 2018]. Сначала (2007 г.) был отменен так называемый национально-региональный компонент базового учебного плана, затем новый Федеральный закон об образовании 2012 г. подтвердил, что региональные власти в целом отстранены от принятия решений о содержании и структуре образовательного процесса, а в последние годы произошло резкое ускорение унификации и, по сути, русификации. Среди симптоматичных событий - высказывание В.В. Путина на заседании Совета по межнациональным отношениям в июле 2017 г. о недопустимости принуждения к изучению государственных языков республик ${ }^{5}$ и поправки к Закону об образовании (2018 г.), согласно которым государственные языки в республиках могут изучаться только в качестве «родных» языков, а выбор языка в качестве родного является по закону добровольным [Мартынова 2019].

Наконец, наметился «русоцентричный» тренд в символической политике: это и учреждение в 2006 г. Дня народного единства, с символами которого довольно трудно отождествиться этнически нерусским, и запуск руководством партии «Единая Россия» «Русского проекта» (2007 г.), и учреждение в том же году Фонда «Русский мир», и активизация лексики «русскости» в ущерб «российскости» в публичной риторике первых лиц государства.

В марте 2014 г. в речи по случаю присоединения Крыма ${ }^{6}$ В.В. Путин упомянул «русский народ» в однозначно этническом смысле и назвал русских «разделенным» народом. Таким образом, в официальном дискурсе на федеральном уровне произошел важный сдвиг: впервые появился образ русского народа как жертвы внешней силы. Эта общая тенденция стала для некоторых исследователей основанием утверждать, что российские правящие элиты окончательно взяли курс на этнизацию государства [Kolstø 2016; Yusupova 2018].

В Стратегии государственной национальной политики Российской Федерации на период до 2025 г.7 в п. 11 говорится, что "российское государство создавалось как единение народов, системообразующим ядром которого исторически выступал русский народ», который сыграл «объединяющую роль». Обновленный вариант Стратегии ${ }^{8}$ включил также положение о том, что «общероссийская гражданская идентичность основана на сохранении русской культурной доминанты» (п. 11.1), а среди принципов политики была названа «государственная поддержка $<\ldots>>$ этнокультурного развития русского народа и других народов Российской Федерации» (п. 19(e)). Тренд символического закрепления особой роли русских продолжился при внесении поправок в Конституцию РФ: в документ была включена формулировка «язык государствообразующего народа», что без труда интерпретируется как указание на ведущую роль русской этничности в государстве.

Обобщенно говоря, в России в официальном языке, в т. ч. в нормативных документах, начинают воспроизводиться представления об «основной» этнонации

\footnotetext{
5 Заседание Совета по межнациональным отношениям (2017) // Президент России. 20 июля 2017 // http://kremlin.ru/events/councils/by-council/28/55109

6 Обращение Президента Российской Федерации (2014) // Президент России. 18 марта 2014 // http://kremlin.ru/events/president/news/20603

7 Утверждена Указом Президента РФ № 1666 от 19 декабря 2012 г.: https://base.garant.ru/70284810/

8 Утвержден Указом Президента РФ №703 от 6 декабря 2018 г.
} 
как фундаменте государственности и потенциальном объекте особой покровительственной политики. При этом сама официальная позиция остается нечеткой и выражается с рядом оговорок, но сопровождается гомогенизирующей культурной и языковой политикой. В обоснование гомогенизации власти и близкие к ним эксперты используют различную аргументацию, как правило, не связанную с воображаемыми потребностями доминирующей национальности: обычно первыми в списке идут необходимость интеграции и обеспечение гражданского единства, а также защита равных прав и возможностей граждан [Prina 2016].

В то же время центр отдает должное многоэтничности, которая остается (по крайней мере, номинально) адресатом государственной поддержки и заботы. «Русифицирующие» жесты центральной власти отчасти компенсируются акциями в поддержку многонациональности и многоконфессиональности. Сохраняются публичные учреждения культуры и образования, призванные поддерживать языки, искусство и наследие нерусских народов, хотя и без специальных законодательных гарантий. Региональные и муниципальные власти финансируют публичные празднования, демонстрирующие этническое разнообразие населения (фестивали национальных культур, Сабантуй, дни тех или иных национальностей, выставки, концерты и пр.) $)^{9}$. Этнические ассоциации разных уровней также пользуются прямой поддержкой властей, включая финансирование, причем их деятельность ограничивается бюрократически заданной повесткой - развитием фольклора либо пропагандой общероссийского национального единства.

\section{Казахстан}

К моменту распада СССР титульная национальность в Казахской ССР была в меньшинстве: казахи составляли примерно 39,7\% населения [Национальный состав 2009]; однако к настоящему времени их доля превысила $60 \%$, при этом русские остаются второй по численности группой, другие этнические категории составляют не менее $1 / 6$ части населения. В лингвистическом отношении Казахстан представлял и до сих пор представляет собой одну из наиболее русифицированных (помимо России) союзных республик: русский язык безусловно доминирует и в официальной сфере, и в повседневной коммуникации, особенно в городах [Алтынбекова 2006; Dave 2007; Olcott 2002].

С момента получения независимости правящие круги достаточно ясно продемонстрировали, что Казахстан будет строиться как государство, защищающее приоритетную роль и интересы этнических казахов. При этом и руководство, и президент Н.А. Назарбаев, устанавливавший режим личной власти, в качестве потенциальных угроз рассматривали как казахский радикальный национализм, так и недовольство неказахского населения, которое могло привести к сепаратизму и вмешательству извне [Келльнер-Хайнеке, Ландау 2015; Olcott 2002]. Впоследствии элиты продолжили придерживаться политики балансирования и поиска компромиссов, стремясь предотвратить расколы, конфликты и потерю управляемости

\footnotetext{
9 Подробные обзоры этой активности можно найти на портале «Национальный акцент» Гильдии межэтнической журналистики: https://nazaccent.ru/content/news/
} 
[Dave 2007; Ó Beacháin, Kevlihan 2013]. Речь идет о поддержании символического и институционального баланса в нескольких измерениях. Во-первых, укрепление этнического профиля страны, а следовательно, приоритетной роли этнических казахов проводится не в ущерб сохранению лояльности нетитульного населения (в основном русских) [Kolstø 1998; Rees, Williams 2017]. Во-вторых, укрепление казахского языка в качестве единственного государственного сталкивается с реальным доминированием русского языка, де-факто выступающим основным средством коммуникации. В-третьих, власти с их стремлением не создавать предпосылок для выражения групповых требований и мобилизации на этнической основе вступают в конфликт со здравым смыслом, сформированным десятилетиями жизни при советской власти и свидетельствующим о существенных отличиях в интересах разных национальностей.

Обе конституции независимого Казахстана (1993 г. и ныне действующая 1995 г.) содержат формулировки, указывающие на особое положение этнических казахов, но последовательно утверждают равенство и солидарность всех граждан. В преамбуле конституции говорится о создании государственности на «исконной казахской земле». При этом конституция провозглашает в качестве основополагающих принципов общественное согласие, политическую стабильность и казахстанский патриотизм, запрещая нарушение равных прав граждан и пропаганду превосходства, в т. ч. по расовому и национальному признакам. Казахский язык объявлен единственным государственным языком, но конституционная норма (ст. 7 (2)) и Закон «О языках» (1997 г.)) оговаривают, что русский используется наравне с казахским в системе государственного управления и местного самоуправления.

Казахская конституция провозглашает унитарный характер государства и объявляет неконституционными любые действия, «способные нарушить межнациональное и межконфессиональное согласие». Унитаризм при этом толкуется достаточно широко: это не просто унифицированная система управления, но и недопущение территориальной автономии и любых групповых требований [Ертысбаев 2001; Султанов 2011]. Этническая и языковая неоднородность казахстанского общества признается, но на индивидуальном уровне: в ст. 7 говорится о «языках народа Казахстана» (выделено нами - В.М., А.О.), в ст. 19 о праве пользования родным языком и о праве определять и указывать в числе прочего национальную принадлежность. Таким образом, потенциально конфликтогенные положения (установление этнической основы государственности, признание этнической и языковой неоднородности, запрет групповых требований) замалчиваются, артикулируются нечетко и уравновешиваются другими формулировками.

В официальных документах и выступлениях высокопоставленных чиновников можно встретить немало указаний на особую роль казахов как основы государственности [Доктрина 2010; Schatz 2000]; а практическая политика, включая утверждение исторической символики и топонимики и репатриацию зарубежных казахов, ведет к укреплению этнического профиля страны [Хименес-Товар 2014; Сулейменова 2011; Cummings 2006; Diener 2009]. В то же время через систему образования и медиа проводится пропаганда, утверждающая необходимость гражданского единства, патриотизма независимо от этнической принадлежности и лояльности действующей власти [Савин 2009; Burkhanov 2017; Kesici 2011]. 
Этнический радикализм и даже любой не устраивающий власти активизм эффективно купируются [Ларуэль, Пейруз 2007; Dave 2007; Oka 2009], благодаря чему поддерживается имидж государства как силы, с одной стороны, защищающей интересы казахов, а с другой, не допускающей притеснений неказахского населения [Ертысбаев 2001; Oka 2009].

Овладение государственным языком объявлено долгом гражданина Казахстана, но до настоящего времени власти не установили квалификационных требований и штрафных санкций, которые обеспечивали бы приоритетное использование казахского языка в публичной сфере. В официальном дискурсе казахский описывается как общее достояние, а всеобщее владение им (наряду с английским и русским) - как условие интеграции общества [Стратегия «Казахстан-2050» 2012]. Власти последовательно расширяют использование казахского языка в официальном делопроизводстве, системе образования и масс-медиа: так, если в 1990/1991 учебном году на казахском учились 32,4\% школьников, то к 2000/2001 г. их доля выросла до 50,7\%, к 2015/2016 г.- до 65,9\% [Алтынбекова 2017].

В Казахстане действуют около тысячи неправительственных организаций, которые выступают от имени разных этнических групп. Все они поставлены под эффективный контроль государства и фактически вынуждены координировать свою деятельность с государственными «Домами дружбы» и с системой Ассамблеи народа Казахстана (АНК) [Жетпысбаев 2017]. Формально АНК представляет собой консультативную структуру, входящую в состав Администрации Президента.

Этнокультурная политика в Казахстане демонстрирует плавную эволюцию и постепенное установление авторитарного контроля над всеми проявлениями этнической отличительности и возможностями выражения претензий на этнической основе. Контроль выражается не только в пресечении нежелательной деятельности, но в активной правительственной пропаганде гражданского единства при замалчивании неудобных тем, а также в формировании институтов, дающих возможности демонстрировать этнические различия и в кооптации персон, способных заниматься такой деятельностью.

\section{Украина}

К 1989 г. на Украине этнические украинцы составляли 72,7\% населения [Всесоюзная перепись населения 1989], однако в языковом отношении страна оставалась сильно русифицированной [Плеханов 2019; Besters-Dilger 2008]: русский язык доминировал в системе образования и во всех публичных коммуникациях. В начале 1990-х только 44\% населения предпочитали пользоваться украинским языком [Kulyk 2014, p. 204].

К моменту распада СССР руководство Украины и его фактический союзник - националистическое движение - были озабочены возможной негативной реакцией населения на разрыв связей с союзным центром и на политику украинизации. Это вынудило украинские власти приложить усилия, чтобы убедить представителей всех национальностей в том, что суверенизация страны означает общий выигрыш и что права меньшинств будут защищены [Motyl 1993; Strayer 1998]. 
Конституция, принятая в июне 1996 г. $^{10}$, утверждает дуальную - гражданскую и этническую - легитимность государства. Преамбула вводит категорию «украинский народ», который описывается как «граждане Украины всех национальностей». При этом украинская государственность основывается на «осуществленном украинской нацией, всем украинским народом правом на самоопределение». Таким образом, Конституция проводит различие между «украинским народом» и «украинской нацией», где под последней понимаются этнические украинцы. Ст. 11 Конституции также подчеркивает различие между этнической «украинской нацией» и другими группами населения. Ст. 10 закрепляет за украинским языком статус единственного государственного языка; этой же статьей гарантируются развитие, использование и защита русского и других языков национальных меньшинств. Русский, таким образом, выделен особо, но отнесен к языкам национальных меньшинств, хотя фактически он играет роль lingua franca. Ст. 1 Закона «О национальных меньшинствах в Украине» ${ }^{11}$ определяет национальные меньшинства как граждан Украины, не являющихся украинцами по национальности, и содержит общие положения о равенстве прав граждан, равный доступ к публичным должностям, право на выбор национальной принадлежности, право на объединение и ряд других прав. Закон носит рамочный характер, и отношения властей с меньшинствами складываются в зависимости от местной ситуации и на основе неформальных договоренностей.

Наиболее острым вопросом остается языковое регулирование. Основную тенденцию языковой политики Украины можно описать как медленное, неравномерное и постепенное расширение сферы использования государственного языка и сокращение пространства русского языка. Высшее и среднее образование в значительной степени, по крайней мере формально, переведено на государственный язык. Доля учеников в школах с украинским языком обучения в 1990/1991 г. составляла 47,9\%, а в 2010/2011 г. - 82,3\% [Арефьев 2018; Лапина 2018]. Украинский является обязательным языком официального делопроизводства и коммуникации, при этом русский в значительной степени сохранил свои позиции в качестве основного средства общения в неофициальной сфере: бизнесе, средствах массовой информации, культуре и науке. В официальной сфере позиции русского языка также фактически долгое время сохранялись, отчасти из-за неформально сложившихся отношений и возможности обходить требования закона на практике [Polese 2010; Polese 2011].

Реальная ситуация на Украине определяется не столько желанием правительства, сколько соперничеством разных политических сил и необходимостью выстраивания компромиссов, а также слабой эффективностью госаппарата. С момента получения независимости языковая политика (шире - политика «национализации») испытывала значительные колебания: периоды радикализации этой политики сменялись (с приходом к власти новых политических сил) смягчением и откатом назад. Для президентства Леонида Кравчука (1991-1994 гг.) была характерна официальная риторика украинизации, но при этом прослеживалась ограниченность практических шагов [Arel 1995; Kulyk 2006, p. 295].

\footnotetext{
10 http://search.ligazakon.ua/1_doc2.nsf/link1/Z960254K.html

11 http://search.ligazakon.ua/1_doc2.nsf/link1/T249400.html
} 
Во время правления Леонида Кучмы (1994-2004 гг.) власть демонстрировала эклектику и непоследовательность [Портнов 2010, с. 40-68]. Когда президентом стал Виктор Ющенко (2005-2010 гг.), руководство страны развернуло ускоренную украинизацию в языковой сфере и в производстве национальных нарративов [Касьянов 2019]. При президентстве Виктора Януковича (2010-2014 гг.) произошел откат в обратную сторону - к либерализации языковой политики и отказу от националистической риторики [Podolian 2015]. После отстранения В. Януковича от власти в феврале 2014 г. Верховная Рада проголосовала за отмену либерального Закона об основах языковой политики, но эта попытка была заблокирована и.о. президента. Что касается периода вооруженного конфликта на востоке, то в начальной фазе официальные власти и основные политические силы избегали радикальной националистической риторики, предпочитая дискурс политической украинской нации и единство согражданства независимо от языка и происхождения.

Со временем наметился возврат к политике «национализации» в использовании языка и государственной символики. В качестве основных аргументов использовались якобы дезинтегрированность украинского общества, по-прежнему «ущемленное» положение украинского языка, а также воздействие «мягкой силы» России, проводимой посредством культурной продукции на русском языке и пропаганды через СМИ и социальные сети. В 2015-2016 гг. были введены языковые квоты на радио- и телевещании, а также ограничены распространение российской печатной продукции и пользование российскими социальными сетями; позднее этот набор дополнился необходимостью избавления от «имперского» культурного наследия [Галкина 2019].

В сентябре 2017 г. был принят новый Закон об образовании, предусматривающий полный перевод школьной системы на государственный язык при сохранении возможности преподавания в ограниченном объеме языков меньшинств (только для лиц, относящихся к соответствующим меньшинствам). Этот подход был подтвержден Законом об общем среднем образовании в январе 2020 г. В качестве основного довода власти ссылались на необходимость обеспечить выпускникам школ равные возможности на рынке труда [Закон України 2017; Тищенко 2017].

25 апреля 2019 г. Верховная Рада приняла закон «Об обеспечении функционирования украинского языка как государственного языка» ${ }^{12}$, подтверждающего конституционное положение, что украинский язык является единственным государственным языком и что государство должно принудительно обеспечить его функционирование во всех сферах публичной жизни. Этот нормативный акт вступил в силу накануне прихода к власти Владимира Зеленского ${ }^{13}$, который своим успехом во многом был обязан тому обстоятельству, что не использовал в предвыборной кампании националистическую повестку, к которой большинство избирателей и так было равнодушно. Тем не менее новая власть, не встречая запроса на «национализацию», не стала пересматривать курс прежнего руководства.

\footnotetext{
12 Закон № 2704-VIII от 25 апреля 2019 г.
}

13 Избран президентом в апреле 2019 г., возглавляемая им партия «Слуга народа» получила парламентское большинство в июле того же года. 


\section{Инерционный сценарий}

После крушения СССР «национализирующие» интонации присутствовали в официальной риторике и в Казахстане, и на Украине, но в действие они конвертировались эпизодически и непоследовательно. Что касается России, то в этом случае можно говорить о трендах гомогенизации, а не о прямых аналогах «национализирующей» политики прежде всего потому, что требования восстановить Россию как государство этнических русских, хотя и встречались в публичном пространстве, все же не получили заметного распространения. Наконец, политика поддержки соотечественников, заявленная в каждой из трех стран в 1990-2000-е гг., не сыграла существенной роли в межгосударственных отношениях.

Для этнокультурной политики России, Казахстана и Украины характерно то, что выше было обозначено как стратегическая амбивалентность. В официальных нарративах на Украине и в Казахстане совмещаются, с одной стороны, акцентирование особой роли титульных национальностей и необходимости укрепления их языков и культур, а с другой стороны, признание гражданского равноправия и осуществления власти от имени всех граждан, независимо от национальности и языка. В обеих странах власти на всех уровнях стремятся поддерживать имидж центристов, отвергающих опасные крайности [Burkhanov 2017; Kulyk 2006; Shevel 2011]. При этом общие законодательные установки, предполагающие приоритет единственного государственного языка, проводятся в жизнь ограниченно и в целом позволяют русскому языку сохраняться в качестве lingua franca. B Pocсии ситуация представляется более сложной ввиду особенностей федеративного устройства и проведения отдельными республиками собственной языковой и этнической политики. Однако для центральной власти риторика многонациональности не исключает символического признания особой роли этнических русских, обеспечения фактической монополии русского языка в публичных коммуникациях и внедрения общих для всей страны национальных символов и стандартов в образовании.

Следует подчеркнуть, что во всех трех странах отсутствует одна из вершин «треугольника» Р. Брубейкера - массовая мобилизация нетитульных меньшинств. Эмпирические данные по всем постсоветским государствам показывают, что только в единичных случаях население демонстрирует способность к самоорганизации вне государственных институтов и протесту и что массовое участие обычно сменяется демобилизацией. Хотя в постсоветских государствах были и остаются общественные организации, выступающие за права русскоязычного населения, в целом это население демонстрирует конформизм и индифферентность, в т. ч. в отношении «национализирующей» политики. В России массовые движения на этнической основе в республиках были ощутимым фактором лишь в начале 1990-х гг, а затем стали в целом маргинальным явлением.

При отсутствии общего теоретического объяснения этого феномена можно сделать отсылки к частным интерпретациям. Во-первых, важную роль играет так называемое негативное равновесие [Гельман 2018] - стремление людей избегать перемен и оставаться в той системе отношений, к которой удалось приспособиться [Green 2018], когда структура повседневности и культурная среда остаются на протяжении длительного времени неизменными или меняются медленно, что 
облегчает индивидуальную адаптацию. Во-вторых, необходимо учитывать систему экономической и политической зависимости населения от государственных и бизнес-структур [Allina-Pisano 2010; Mamonova 2019], которую в целом можно описывать как патримониализм [Fisun 2012; Hale 2015]. В-третьих, в анализируемых трех странах широко распространены неформальные практики и институты, позволяющие обходить формальные правила или приспосабливать их к индивидуальным текущим нуждам [Isaacs, Polese 2015; Polese 2011].

В подобном обществе эклектика, унаследованная от советского периода, создает оптимальный модус этнокультурной политики. В свою очередь эти факторы формируют дополнительные стимулы для оппортунистического и конформистского поведения. Люди, имеющие разные представления о желаемой для себя конфигурации нации - более жесткой «национализации» - или о сохранении статускво, могут найти для себя приемлемые элементы в предложенном государством эклектическом наборе идей и практических подходов, в результате чего возникают ожидания, блокирующие участие в протестной активности.

Если отвлечься от деталей внутриполитических процессов и демографической ситуации, то можно привести два фоновых обстоятельства и два тренда, свойственные всем рассматриваемым странам. Во всех трех государствах сохраняются в основе своей советские официальные шаблоны описания этнического и языкового разнообразия, а также практики его организации со стороны законодателя и исполнительной власти; везде фоном служат пассивность населения и предпочтение индивидуальной адаптации коллективному действию; везде государственный аппарат демонстрирует стимулы к централизующей и унифицирующей внутренней политике, что означает и культурную гомогенизацию с укреплением позиций единственного государственного языка; во всех трех государствах гомогенизирующая политика опирается на дуальную - общегражданскую и этническую - легитимацию.

Перечисленные фоновые обстоятельства и тренды означают воспроизводство дискурсивных и социальных форм, унаследованных от советского периода, в силу чего имеет смысл рассматривать инерциионой сценарий.

\section{Итоги: насколько устойчив статус-кво?}

Мы видим, что к середине 2010-х гг. инерционный сценарий в России и Украине начал давать сбои: произошел поворот к реальной «национализации», закрепляемой в организационных изменениях и механизмах принуждения. Почему такой сдвиг наблюдался в России и Украине, но не в Казахстане? Чем определяется устойчивость постсоветского модуса этнокультурной политики?

Проще всего объясняется ситуация на Украине. После начала конфликта с Россией в 2014 г. там сформировался относительно широкий общественный консенсус относительно необходимости национальной консолидации. Во всяком случае, в условиях войны голоса против «национализации» государства и дерусификации социокультурной сферы не имеют такого веса, как раньше. Если прежде внутреннюю политику можно было сравнивать с маятником (радикализация «национализирующего» тренда сменялась либерализацией), то в последние годы 
маятник замер в крайнем положении. Триггером перемен в украинской этнокультурной политике стал внешний фактор, а ее драйвером выступило государство с изменившимися мотивациями и возможностями.

В России поворот к «национализации» также совпал с переменами во внешней политике. Конфронтация с Западом, стартовавшая в конце 2000-х гг. и усилившаяся после присоединения Крыма и начала войны на востоке Украины, сопровождалась более энергичной официальной риторикой национального единства в условиях враждебного окружения. Новый курс включает в себя стратегию внешней экспансии России с помощью распространения русского языка и культуры, а также с опорой на русское и русскоязычное население за рубежом. Этот дискурс имел и имеет отчетливые культурные обертоны, от которых остается короткая дистанция до концепта «государствообразующего народа». Концепты «русского мира» и «разделенного народа», становящегося жертвой враждебных сил, в еще большей степени стимулируют «этнизирующее» восприятие внутренних и внешнеполитических процессов. Административная централизация и унификация не могут не затронуть сферы образования, языковой политики и медиа, что на практике также означает культурную гомогенизацию. Как и на Украине, перемены в России проводятся в жизнь государственным аппаратом, получившим новые возможности и ставящим перед собой новые цели.

В Казахстане же наблюдается продолжение предыдущего тренда сохранения и укрепления этнического профиля страны: здесь видна плавная эволюция, ведущая к укреплению позиций казахского языка и символической роли казахской этничности, а также к более эффективному контролю правительства за выражением этнического разнообразия в публичной сфере. Вертикаль контроля и управления выстраивалась давно, и она оказалась вполне готовой к вызовам наподобие «русского мира».

Обобщенно говоря, нарушение равновесия в рассматриваемых случаях связано с радикальными сдвигами внешнеполитического характера. Появление у централизованного консолидированного государства амбициозного проекта меняет внутриполитическую конфигурацию и запускает процессы, которые выглядят как «национализация», при этом внешняя угроза и необходимость мобилизации для противодействия также вызывают подобный эффект. Сами по себе механизмы инерционного сценария, основанные на гибком оппортунистическом поведении элит и пассивном приспособлении масс, не ставятся под вопрос. Речь идет о новом равновесии, и отсутствие сильного внешнего импульса оставляет равновесие в целом неизменным, как в Казахстане.

\section{Литература}

Алтынбекова О.Б. (2006) Этноязыковые процессы в Казахстане. Алматы: Экономика. Алтынбекова О.Б. (2017) Динамика языковых изменений в сфере школьного образования Казахстана // Текст культуры и культура текста. Материалы IV Международного педагогического форума. СПб.: Общество преподавателей русского языка и литературы. С. 595-599.

Арефьев А.Л. (2018) Русскоязычное образование на Украине - история и современность // Вестник Российской академии наук. Т. 88. № 12. С. 1090-1099. 
Беспамятных Н., Осипов А., Василевич А., Прина Ф., Пушкин И. (2014) Политика управления этнокультурным разнообразием в Беларуси, Молдове и Украине: между советским наследием и европейскими стандартами. Вильнюс: ЕГУ.

Всесоюзная перепись населения 1989 г. Распределение населения Украинской ССР по наиболее многочисленным национальностям и языку // Демоскоп Weekly // http://www.demoscope.ru/weekly/ssp/sng_nac_lan_89_uk.php

Галкина Е. (2019) Выборы со взломом: почему победй Зеленский // Сноб. 22 апреля 2019 // https://snob.ru/entry/175930

Гельман В. (2018) Негативное равновесие // The New Times. 24 декабря 2018 // https://newtimes.ru/articles/detail/175194/

Деятельность Ассамблеи народа Казахстана // Ассамблея народа Казахстана // https://assembly.kz/ru/ank/deyatelnost-assamblei-naroda-kazakhstana

Доктрина Национального единства Казахстана (2010) // Ассамблея народа Казахстана. 19 апреля 2010 // https://online.zakon.kz/document/?doc_id=30501158\#pos=6;-155

Ертысбаев Е. (2001) Казахстан и Назарбаев: логика перемен̆. Астана: Елорда.

Жакаева Л.С. (2009) О пропорциональной системе формирования Мажилиса парламента Казахстана // Конституционное и муниципальное право. № 7. С. 27-32

Жетпысбаев С.К. (2017) Этнокультурные объединения в Республике Казахстан и их роль в консолидации гражданского общества // Гуманитарные науки в Сибири. Т. 24. № 1. С. 86-90.

Закон України «Про освіту» спрямований на забезпечення рівних можливостей для всіх громадян України на здобуття вищої освіти (2017) // Міністерство закордонних справ України. 15 вересня 2017 // https://mfa.gov.ua/news/59779-zakon-ukrajini-pro-osvituspryamovanij-na-zabezpechennya-rivnih-mozhlivostej-dlya-vsih-gromadyan-ukrajini-nazdobuttya-vishhoji-osviti

Зевелев И.А. (2008) Соотечественники в российской политике на постсоветском пространстве: наследие империи и государственный прагматизм // Миллер А.И. (ред.) Наследие империй и будущее России. М.: Новое литературное обозрение. С. 241-293.

Кадыржанов Р.К. (2014) Этнокультурный символизм и национальная идентичность Казахстана. Алматы: Институт философии, политологии и религиоведения КН МОН РК.

Касьянов Г. (2019) Украина и соседи. Историческая политика. 1987-2018. М.: Новое литературное обозрение.

Келльнер-Хайнкеле Б., Ландау Я.М. (2015) Языковая политика в современной Центральной Азии: национальная и этническая идентичность и советское наследие. М.: Центр книги Рудомино.

Лапина Л.А. (2018) Украинский язык в системе школьного и вузовского образования в Украине 1989-2012 гг. // Эрлихсон И.М., Савосина Ю.В., Лосева Ю.И. (ред.) Европа, Россия, Азия: сотрудничество, противоречия, конфликты. Сборник статей III Международной научно-практической конференции. Рязань: Рязанский государственный университет им. С.А. Есенина. С. 235-241.

Ларюэль М., Пейруз С. (2007) «Русский вопрос» в независимом Казахстане: история, политика, идентичность. М.: Наталис.

Мартынова М.Ю. (2019) Язык и школьное образование: российский опыт // Филиппова Е.И., Соколовский С.В. (ред.) Смерть языка - смерть народа? Языковые ситуации и языковые права в России и сопредельных государствах. М.: Институт этнологии и антропологии им. Н.Н. Миклухо-Маклая РАН, Горячая линия - Телеком. С. 40-74.

Миллер А. (2008) История империй и политика памяти // Россия в глобальной политике. № 4 // https://globalaffairs.ru/articles/istoriya-imperij-i-politika-pamyati/

Морозов А.А. (2005) Казахстан за годы независимости. Алматы: КИСИ при Президенте РК.

Население, учтенное при Всероссийской переписи населения 2010 года (2010) // Федеральная служба государственной статистики // http://www.gks.ru/free_doc/new_site/perepis2010/croc/perepis_itogi1612.htm

Национальный состав, веройсповедание и владения языками в Республике Казахстан (2009) // Бюро национальной статистики Агентства по стратегическому планированию и реформам Республики Казахстан // https://stat.gov.kz/census/national/2009/general 
Паин Э.А. (2004) Этнополитический маятник: динамика и механизмы этнополитических процессов в постсоветской России. М.: Институт социологии РАН.

Плеханов А.А. (2019) Негосударственный язык: законодательное положение русского языка в постсоветской Украине // Филиппова Е.И., Соколовский С.В. (ред.) Смерть языка - смерть народа? Языковые ситуации и языковые права в России и сопредельных государствах. М.: Институт этнологии и антропологии им. Н.Н. Миклухо-Маклая РАН, Горячая линия - Телеком. С. 187-231.

Портнов А. (2010) Упражнения с историей по-украински. М.: ОГИ; Полит.ру; Мемориал.

Савин И.С. (2009) Казахстанская нация сегодня: основные проблемы и перспективы // Вестник Российской нации. № 4(6). С. 205-223.

Стратегия «Казахстан-2050» (2012) // Президент Казахстана // http://www.akorda.kz/ru/official_documents/strategies_and_programs

Сулейменова Э.Д. (2011) Языковые процессы и политика. Алматы: Қазақ унив.

Султанов Б.К. (ред.) (2011) Казахстан: 20 лет независимости. Алматы: КИСИ при Президенте РК.

Тищенко К. (2017) Освіта для нацменшин українською. Як це буде, пояснює Лілія Гриневич // Українска правда. 8 листопада 2017 // http://life.pravda.com.ua/society/2017/11/8/227339/

Хименес-Товар С. (2014) «Казахстанизация» Казахстана: языковая политика, национализм и этнические меньшинства // Этнографическое обозрение. № 4. С. 27-35.

Численность учащихся по языкам обучения в общеобразовательных школах // Бюро национальной статистики Агентства по стратегическому планированию и реформам Республики Казахстан // https://stat.gov.kz/official/industry/62/statistic/7

Allina-Pisano J. (2010) Social Contracts and Authoritarian Projects in post-Soviet Space: The Use of Administrative Resource // Communist and Post-Communist Studies, vol. 43, no 4, pp. 373-382.

Arel D. (1995) Language Politics in Independent Ukraine: Towards One or Two State Languages? // Nationalities Papers, vol. 23, no 3, pp. 597-622.

Besters-Dilger J. (ed.) (2008) Language Policy and Language Situation in Ukraine: Analysis and Recommendations, Frankfurt am Main: Peter Lang.

Brubaker R. (1996) Nationalism Reframed. Nationhood and the National Question in the New Europe, Cambridge: Cambridge University Press.

Brubaker R. (2011) Nationalizing States Revisited: Projects and Processes of Nationalization in Post-Soviet States // Ethnic and Racial Studies, vol. 34, no 11, pp. 1785-1814.

Burkhanov A. (2017) Kazakhstan's National Identity - Building Policy: Soviet Legacy, State Efforts, and Societal Reactions // Cornell International Law Journal, vol. 50, no 1, pp. 1-14.

Cummings S.N. (2006) Legitimation and Identification in Kazakhstan // Nationalism and Ethnic Politics, vol. 12, no 2, pp. 177-204.

Dave B. (2007) Kazakhstan. Ethnicity, Language and Power, London: Routledge.

Diener A.C. (2009) One Homeland or Two?: The Nationalization and Transnationalization of Mongolia's Kazakhs, Washington: Woodrow Wilson Center Press; Stanford, CA: Stanford University Press.

Fisun O. (2012) Rethinking Post-Soviet Politics from a Neopatrimonial Perspective // Demokratizatsiya: The Journal of Post-Soviet Democratization, vol. 20, no 2, pp. 87-96.

Giuliano E., Gorenburg D. (2012) The Unexpectedly Underwhelming Role of Ethnicity in Russian Politics, 1991-2011// Demokratizatsiya: The Journal of Post-Soviet Democratization, vol. 20, no 2, pp. 175-188.

Greene S.A. (2018) Running to Stand Still: Aggressive Immobility and the Limits of Power in Russia // Post-Soviet Affairs, vol. 34, no 5, pp. 333-347.

Hale H.E. (2015) Patronal Politics: Eurasian Regime Dynamics in Comparative Perspective, Cambridge: Cambridge University Press.

Isaacs R., Polese A. (2015) Between 'Imagined' and 'Real' Nationbuilding: Identities and Nationhood in post-Soviet Central Asia // Nationalities Papers, vol. 43, no 3, pp. 371-382.

Kesici Ö. (2011) The Dilemma in the Nation-Building Process: The Kazakh or Kazakhstani Nation? // Journal on Ethnopolitics and Minority Issues in Europe, vol. 10, no 1, pp. 31-58.

Kolstø P. (1998) Anticipating Demographic Superiority: Kazakh Thinking on Integration and Nation Building // Europe-Asia Studies, vol. 50, no 1, pp. 51-69. 
Kolstø P. (2016) The Ethnification of Russian Nationalism // The New Russian Nationalism. Imperialism, Ethnicity and Authoritarianism. 2000-2015 (eds. Kolstø P., Blakkisrud H.), Edinburgh: Edinburgh University Press, pp. 18-45.

Kulyk V. (2006) Constructing Common Sense: Language and Ethnicity in Ukrainian Public Discourse // Ethnic and Racial Studies, vol. 29, no 2, pp. 281-314.

Kulyk V. (2014) Soviet Nationalities Policies and the Discrepancy between Ethnocultural Identification and Language Practice in Ukraine // Historical Legacies of Communism in Russia and Eastern Europe (eds. Beissinger M., Kotkin S.), New York: Cambridge University Press, pp. 202-221.

Mamonova N. (2019) Understanding the Silent Majority in Authoritarian Populism: What Can We Learn from Popular Support for Putin in Rural Russia? // The Journal of Peasant Studies, vol. 46, no 3, pp. 561-585.

Martin T. (2001) The Affirmative Action Empire: Nations and Nationalism in the Soviet Union, 1923-1939, Ithaca; London: Cornell University Press.

Motyl A.J. (1993) Dilemmas of Independence: Ukraine after Totalitarianism, New York: Council on Foreign Relations.

Ó Beacháin D., Kevlihan R. (2013) Threading a Needle: Kazakhstan between Civic and Ethnonationalist State-building // Nations and Nationalism, vol. 19, no 2, pp. 337-356.

Oka N. (2009) Ethnicity and Elections under Authoritarianism: The Case of Kazakhstan // IDE Discussion Paper. No. 194 // https://www.ide.go.jp/English/Publish/Download/Dp/194.html

Olcott M.B. (2002) Kazakhstan: Unfulfilled Promise, Washington DC: Carnegie Endowment for International Peace.

Podolian O. (2015) Language Policy and the Discourse on Languages in Ukraine under President Viktor Yanukovych // Europe-Asia Studies, vol. 67, no 9, pp. 1512-1514.

Polese A. (2010) The Formal and the Informal: Exploring 'Ukrainian' Education in Ukraine, Scenes from Odessa // Comparative Education, vol. 46, no 1, pp. 47-62.

Polese A. (2011) Language and Identity in Ukraine: Was It Really Nation-Building? // Studies of Transition States and Societies, vol. 3, no 3, pp. 36-50.

Prina F. (2016) National Minorities in Putin's Russia. Diversity and Assimilation, New York: Routledge.

Rees K.M., Williams N.W. (2017) Explaining Kazakhstani Identity: Supraethnic Identity, Ethnicity, Language, and Citizenship // Nationalities Papers, vol. 45, no 5, pp. 815-839.

Schatz E.A. (2000) Framing Strategies and Non-Conflict in Multi-ethnic Kazakhstan // Nationalism and Ethnic Politics, vol. 6, no 2, pp. 71-94.

Shevel O. (2010) The Post-Communist Diaspora Laws. Beyond the "Good Civic versus Bad Ethnic" Nationalism Dichotomy // East European Politics \& Societies, vol. 24, no 1, pp. 159-187.

Shevel O. (2011) Russian Nation-building from Yel'tsin to Medvedev: Ethnic, Civic or Purposefully Ambiguous? // Europe-Asia Studies, vol. 63, no 2, pp. 179-202.

Slezkine Y. (1994) The USSR as a Communal Apartment, or How a Socialist State Promoted Ethnic Particularism // Slavic Review, vol. 53, no 2, pp. 414-452.

Strayer R.W. (1998) Why Did the Soviet Union Collapse?: Understanding Historical Change, New York \& London; M.E. Sharpe.

Suny R. (1993) The Revenge of the Past: Nationalism, Revolution, and the Collapse of the Soviet Union, Stanford: Stanford University Press.

Tishkov V. (1997) Ethnicity, Nationalism and Conflict in and after the Soviet Union: the Mind Aflame, London: Sage Publications.

Yusupova G. (2018) Cultural Nationalism and Everyday Resistance in an Illiberal Nationalising State: Ethnic Minority Nationalism in Russia // Nations and Nationalism, vol. 4, no 3, pp. $624-647$.

Zamyatin K. (2018) Russian-Speaking Nation? The Promotion of the Russian Language and Its Significance for Ongoing Efforts at the Russian Nation-Building // The Politics of Multilingualism: Linguistic Governance, Globalisation and Europeanisation (eds. Grin F., Kraus P.), Amsterdam: John Benjamins, pp. 39-64. 


\title{
The Dynamics of Ethnocultural Policy in Russia, Kazakhstan and Ukraine: Delayed "Nationalization"? ${ }^{14}$
}

\author{
V. MALAKHOV*, A. OSIPOV**
}

\begin{abstract}
*Vladimir Malakhov - DSc in Politics, Director, Centre for Political Theory and Applied Political Science, Russian Presidential Academy of National Economy and Public Administration. Address: 82, Vernadskogo Av., Moscow, 119571, Russian Federation. E-mail: vmalachov@yandex.ru

**Alexandr Osipov - PhD in History, Board Member, International Centre for Ethnic and Linguistic Diversity Studies. Address: Korunní 2569/108, 10100 Praha 10, Czechia. E-mail: aosipov1@gmail.com
\end{abstract}

Citation: Malakhov V., Osipov A. (2021) The Dynamics of Ethnocultural Policy in Russia, Kazakhstan and Ukraine: Delayed "Nationalization"? Mir Rossii, vol. 30, no 2, pp. 26-47 (in Russian). DOI: 10.17323/1811-038X-2021-30-2-26-47

\section{Abstract}

This article focuses on the origins, driving forces and dynamics of the so-called ethnocultural policy in the three largest post-Soviet countries: Russia, Kazakhstan and Ukraine. The authors analyze why the empirical realities did not correspond to the expectations of the 1990s that nation-building in post-Soviet countries would be of repressive character but which have started to partly materialize recently. In the mid-1990s, Rogers Brubaker supposed that the newly independent countries would pursue a policy of "nationalization", or, in other words, the "restoration" of the social and cultural positions of their founding, or "core" ethnic nations. Such a strategy was supposed to provoke resistance among ethnic minorities, primarily Russians, and conflicts with the countries backing and patronizing their kin minorities. However, the actual processes followed a different scenario which was based on "strategic ambiguity". The latter included ideological eclecticism and legal uncertainty in the formulation and pursuit of governmental policies. Uncertainty in official action went along with the lack of mass mobilization and mass protests on ethnic grounds.

The analysis is based on the examination of the institutional design of ethnocultural policies. The authors conclude that the post-Soviet developments pertinent to ethnocultural diversity can be explained by the Soviet institutional legacy and described as an inertial scenario. In all three countries, official discourse combines the recognition of the special role of the ethnic majority as the basis of statehood and concurrently the values of civic unity and ethnocultural diversity. In all cases, governments seek to strengthen the position of the sole state language, but at the same time they create or tolerate institutional opportunities for maintaining multilingualism in the public space. Ethnocultural legitimization is combined with civic justifications resting on the mottos of equality and solidarity of individuals regardless of ethnicity. The authors also answer the question

14 The article was prepared in the framework of a research grant funded by the Ministry of Science and Higher Education of the Russian Federation (grant ID: 075-15-2020-908). 
of why the ruling elites in Russia and Ukraine have opted for more straightforward and pro-active "nationalizing" and homogenizing policies in recent years. They conclude that the inertial scenario is based on a shaky equilibrium and thus it is sensitive to external disturbances, such as interstate conflicts.

Keywords: ethnic and cultural policy, cultural diversity, nation state, nationalizing states, nationalism, Russia, Ukraine, Kazakhstan

\section{References}

Allina-Pisano J. (2010) Social Contracts and Authoritarian Projects in post-Soviet Space: The Use of Administrative Resource. Communist and Post-Communist Studies, vol. 43, no 4, pp. 373-382. Altynbekova O. (2006) Etnoyazykovye protsessy v Kazakhstane [Ethnolinguistic Processes in Kazakhstan], Almaty: Ekonomika.

Altynbekova O. (2017) Dinamika yazykovykh izmeneniy v sfere shkol'nogo obrazovaniya Kazahstana" [The Dynamics of Language Changes in the Sphere of School Education in Kazakhstan]. Tekst kul'tury $i$ kul'tura teksta. Materialy IV Mezhdunarodnogo pedagogicheskogo foruma [The Text of Culture and the Culture of Text. Proceedings of the IV International Pedagogical Forum], Saint Petersburg: The Society of Teachers of Russian Language and Literature, pp. 595-599.

Aref'ev A. (2018) Russoyazychnoe obrazovanie na Ukraine - istoriya i sovremennost' [The Russian-language Education in Ukraine - History and Contemporainty]. Herald of the Russian Academy of Sciences, vol. 88, no 12, pp. 1090-1099.

Arel D. (1995) Language Politics in Independent Ukraine: Towards One or Two State Languages? Nationalities Papers, vol. 23, no 3, pp. 597-622.

Bespamiatnykh N., Osipov A., Prina F., Pushkin I., Vasilevich A. (2014) Politika upravleniya ethnoculturanym raznoobraziem v Belarusi, Moldove i Ukraine [Policies of Ethno-Cultural Diversity Management in Belarus, Moldova and Ukraine], Vilnius: European Humanities University.

Besters-Dilger J. (ed.) (2008) Language Policy and Language Situation in Ukraine: Analysis and Recommendations, Frankfurt am Main: Peter Lang.

Brubaker R. (1996) Nationalism Reframed. Nationhood and the National Question in the New Europe, Cambridge: Cambridge University Press.

Brubaker R. (2011) Nationalizing States Revisited: Projects and Processes of Nationalization in Post-Soviet States. Ethnic and Racial Studies, vol. 34, no 11, pp. 1785-1814.

Burkhanov A. (2017) Kazakhstan's National Identity - Building Policy: Soviet Legacy, State Efforts, and Societal Reactions. Cornell International Law Journal, vol. 50, no 1, pp. 1-14.

Chislennost' uchashchihsya po yazykam obucheniya v obshcheobrazovatel'nyh shkolakh [Number of Students by Language of Instruction in General Education Schools]. Bureau of National Statistics of the Agency for Strategic Planning and Reforms of the Republic of Kazakhstan. Available at: https://stat.gov.kz/official/industry/62/statistic/7, accessed 20.02.2021.

Cummings S.N. (2006) Legitimation and Identification in Kazakhstan. Nationalism and Ethnic Politics, vol. 12, no 2, pp. 177-204.

Dave B. (2007) Kazakhstan. Ethnicity, Language and Power, London: Routledge.

Deyatel'nost' Assamblei Naroda Kazakhstana [The Activities of the Assembly of People of Kazakhstan]. The Assembly of People of Kazakhstan. Available at: https://assembly.kz/ru/ank/deyatelnost-assamblei-naroda-kazakhstana, accessed 20.02.2021.

Diener A.C. (2009) One Homeland or Two?: The Nationalization and Transnationalization of Mongolia's Kazakhs, Washington: Woodrow Wilson Center Press; Stanford, CA: Stanford University Press. 
Doktrina natsional'nogo edinstsva Kazakhstana [Doctrine of National Unity of Kazakhstan] (2010). The Assembly of People of Kazakhstan, April 19, 2010. Available at: https://online.zakon.kz/document/?doc_id=30501158, accessed 20.02.2021.

Ertysbaev E. (2001) Kazahstan i Nazarbaēv: logika peremen [Kazakhstan and Nazarbayev: The Logic of Change], Astana: Elorda.

Fisun O. (2012) Rethinking Post-Soviet Politics from a Neopatrimonial Perspective. Demokratizatsiya: The Journal of Post-Soviet Democratization, vol. 20, no 2, pp. 87-96.

Galkina E. (2019) Vybory so vzlomom: pochemu pobedil Zelenski [Elections Crached Down: Why Zelenski Won]. Snob, April 22, 2019. Available at: https://snob.ru/entry/175930, accessed 20.02.2021.

Gel'man V. (2018) Negativnoye ravnovesiye [Negative Equilibrium]. The New Times, December 24, 2018. Available at: https://newtimes.ru/articles/detail/175194/, accessed 20.02.2021.

Giuliano E., Gorenburg D. (2012) The Unexpectedly Underwhelming Role of Ethnicity in Russian Politics, 1991-2011. Demokratizatsiya: The Journal of Post-Soviet Democratization, vol. 20 , no 2 , pp. $175-188$.

Greene S.A. (2018) Running to Stand Still: Aggressive Immobility and the Limits of Power in Russia. Post-Soviet Affairs, vol. 34, no 5, pp. 333-347.

Hale H.E. (2015) Patronal Politics: Eurasian Regime Dynamics in Comparative Perspective, Cambridge: Cambridge University Press.

Isaacs R., Polese A. (2015) Between 'Imagined' and 'Real' Nationbuilding: Identities and Nationhood in post-Soviet Central Asia. Nationalities Papers, vol. 43, no 3, pp. 371-382.

Jiménez-Tovar S. (2014) “'Kazakhstanizatsiya’ Kazakhstana: yazykovaya politika, natsionalizm i etnicheskiye menshinstva" [The Kazakhstanization of Kazakhstan: Language Policy, Nationalism and Ethnic Minorities]. Ethnographic Review, no 4, pp. 27-35.

Kadyrzhanov R. (2014) Etnokul'turnyi simvolizm i natsional'naya identichnost' Kazahstana [Ethnocultural Symbolism and National Identity of Kazakhstan], Almaty: The Institute of philosophy, political science and religious studies under the Committee of Science of the Ministry of Education and Science of Kazakhstan.

Kasianov G. (2019) Ukraina i sosedi. Istoricheskaya politika. 1987-2018 [Ukraine and the Neighbours. Historical Policy. 1987-2018], Moscow: Novoye Literaturnoye Obozreniye.

Kellner-Heinkele B., Landau J. (2015) Yazykovaya politika v sovremennoy Tsentral'noy Azii: natsionalnaya $i$ ethnicheskaya identichnost' $i$ Sovetskoye naslediye [Language Policy in Modern Central Asia: National and Ethnic Identity and the Soviet Legacy], Moscow: The Rudomino Book Centre.

Kesici Ö. (2011) The Dilemma in the Nation-Building Process: The Kazakh or Kazakhstani Nation? Journal on Ethnopolitics and Minority Issues in Europe, vol. 10, no 1, pp. 31-58.

Kolstø P. (1998) Anticipating Demographic Superiority: Kazakh Thinking on Integration and Nation Building. Europe-Asia Studies, vol. 50, no 1, pp. 51-69.

Kolstø P. (2016) The Ethnification of Russian Nationalism. The New Russian Nationalism. Imperialism, Ethnicity and Authoritarianism. 2000-2015 (eds. Kolstø P., Blakkisrud H.), Edinburgh: Edinburgh University Press, pp. 18-45.

Kulyk V. (2006) Constructing Common Sense: Language and Ethnicity in Ukrainian Public Discourse. Ethnic and Racial Studies, vol. 29, no 2, pp. 281-314.

Kulyk V. (2014) Soviet Nationalities Policies and the Discrepancy between Ethnocultural Identification and Language Practice in Ukraine. Historical Legacies of Communism in Russia and Eastern Europe (eds. Beissinger M., Kotkin S.), New York: Cambridge University Press, pp. 202-221.

Lapina L. (2018) Ukrainsliy yazyk v sisteme shokol'nogo i vuzovskogo obrazovaniya v Ukraine 1989-2012 gg. [The Ukrainian Language in the System of Secondary and Higher Education in Ukraine in 1989-2012]. Evropa, Rossiya, Aziya: sotrudnichestovo, protivorechiya, konflikty. Sbornik statey III Mezhdunarodnoy nauchno-prakticheskoy konferentsii [Europe, Russia, Asia: Cooperation, Contradictions, Conflicts. A Compilation of Paper from the III International Scientific-Practical Conference] (eds. Erlichson I., Savosina Yu., Loseva Yu.), Ryazan': Ryazan’ Sergei Yesenin State University, pp. 235-241.

Laruelle M., Peyrouse S. (2007) “Russiy vopros” v nezavisimom Kazakhstane: istoriya, politika, identichnost' ["Russian Question” in Independent Kazakhstan: History, Politics, Identity], Moscow: Natalis. 
Mamonova N. (2019) Understanding the Silent Majority in Authoritarian Populism: What Can We Learn from Popular Support for Putin in Rural Russia? The Journal of Peasant Studies, vol. 46, no 3, pp. 561-585.

Martin T. (2001) The Affirmative Action Empire: Nations and Nationalism in the Soviet Union, 1923-1939, Ithaca; London: Cornell University Press.

Martynova M.Yu. (2019) Yazyk i shkolnoe obrazovanie: rossiiskij opyt [Language and School Education: the Russian Experience]. Smert' yazyka - smert' naroda? Yazykovyye situatsii $i$ yazykovyye prava $v$ Rossii $i$ sopredel'nykh gosudarstvakh [The Death of the Language - The Death of the People? Linguistic Situations and Language Rights in Russia and Neighbouring Countries] (eds. Filippova E., Sokolovski S.), Moscow: Institute of Ethnology and Anthropology, RAS, Goriachaya Liniya - Telekom, pp. 40-74.

Miller A. (2008) Istoriya imperiy i politika pamyati [The History of Empires and Memory Politics]. Russia in Global Affairs, no 4. Available at: https://globalaffairs.ru/articles/istoriya-imperiji-politika-pamyati/, accessed 20.02.2021.

Morozov A. (2005) Kazakhstan za gody nezavisimosti [Kazakhstan during the Years of Independence], Almaty: KISI under the President of RK.

Motyl A.J. (1993) Dilemmas of Independence: Ukraine after Totalitarianism, New York: Council on Foreign Relations.

Naselenie, uchtennoe pri Vserossiyskoy perepisi naseleniya 2010 goda [Population Recorded in the 2010 Census] (2010). Federal State Statistic Service. Available at: http://www.gks.ru/free_doc/new_site/perepis2010/croc/perepis_itogi1612.htm, accessed 20.02.2021.

Natsionalnyj sostav, veroispovedaniye i vladeniye yazykami v Respublike Kazakhstan [Ethnic Composition, Faith and Languages Command in the Republic of Kazakhstan] (2009). The Bureau of National Statistics of the Agency for Strategic Planning and Reforms of the Republic of Kazakhstan. Available at: https://stat.gov.kz/census/national/2009/ general, accessed 20.02.2021.

Ó Beacháin D., Kevlihan R. (2013) Threading a Needle: Kazakhstan between Civic and Ethnonationalist State-building. Nations and Nationalism, vol. 19, no 2, pp. 337-356.

Oka N. (2009) Ethnicity and Elections under Authoritarianism: The Case of Kazakhstan. IDE Discussion Paper. No. 194. Available at: https://www.ide.go.jp/English/Publish/Download/Dp/194.html, accessed 20.02.2021.

Olcott M.B. (2002) Kazakhstan: Unfulfilled Promise, Washington DC: Carnegie Endowment for International Peace.

Pain E.A. (2004) Etnopolititcheskij mayatnik: dinamika $i$ mekhanismy etnopoliticheskich protsessov v postsovetskoi Rossii [Ethno-political Pendulum: Dynamic and Arrangements of Ethno-political Processes in Post-Soviet Russia], Moscow: Institute of Sociology, RAS.

Plekhanov A.A. (2019) Negosudarstvenny yazyk: zakonodatel'noye polozheniye russkogo yazyka v postsovetskoy Ukraine [A Non-state Language: The Legislative Position of the Russian Language in post-Soviet Ukraine]. Smert' yazyka - smert' naroda? Yazykovyye situatsii $i$ yazykovyye prava $v$ Rossii $i$ sopredel'nykh gosudarstvakh [The Death of the Language - The Death of the People? Linguistic Situations and Language Rights in Russia and Neighbouring Countries] (eds. Filippova E., Sokolovski S.), Moscow: Institute of Ethnology and Anthropology, RAS, Goriachaya Liniya - Telekom, pp. 187-231.

Podolian O. (2015) Language Policy and the Discourse on Languages in Ukraine under President Viktor Yanukovych. Europe-Asia Studies, vol. 67, no 9, pp. 1512-1514.

Polese A. (2010) The Formal and the Informal: Exploring 'Ukrainian' Education in Ukraine, Scenes from Odessa. Comparative Education, vol. 46, no 1, pp. 47-62.

Polese A. (2011) Language and Identity in Ukraine: Was it Really Nation-Building? Studies of Transition States and Societies, vol. 3, no 3, pp. 36-50.

Portnov A. (2010) Uprazhneniya s istoriyey po-ukrainski [Exercises with History: Ukrainian Style], Moscow: OGI; Polit.ru; Memorial.

Prina F. (2016) National Minorities in Putin's Russia. Diversity and Assimilation, New York: Routledge.

Rees K.M., Williams N.W. (2017) Explaining Kazakhstani Identity: Supraethnic Identity, Ethnicity, Language, and Citizenship. Nationalities Papers, vol. 45, no 5, pp. $815-839$. 
Savin I. (2009) Kazakhstanskaya natsiya segodnya: osnovnye problemy i perspektivy [The Kazakhstani Nation Today: The Major Problems and Perspectives]. Vestnik Rossiiskoy Natsii, no 4(6), pp. 205-223.

Schatz E.A. (2000) Framing Strategies and Non-Conflict in Multi-ethnic Kazakhstan. Nationalism and Ethnic Politics, vol. 6, no 2, pp. 71-94.

Shevel O. (2010) The Post-Communist Diaspora Laws. Beyond the "Good Civic versus Bad Ethnic" Nationalism Dichotomy. East European Politics \& Societies, vol. 24, no 1, pp. 159-187.

Shevel O. (2011) Russian Nation-building from Yel'tsin to Medvedev: Ethnic, Civic or Purposefully Ambiguous? Europe-Asia Studies, vol. 63, no 2, pp. 179-202.

Slezkine Y. (1994) The USSR as a Communal Apartment, or How a Socialist State Promoted Ethnic Particularism. Slavic Review, vol. 53, no 2, pp. 414-452.

Strategiya «Kazahstan-2050» [Strategy "Kazakhstan-2050"] (2012). President of Kazakhstan. Available at: http://www.akorda.kz/ru/official_documents/strategies_and_programs, accessed 20.02.2021.

Strayer R.W. (1998) Why Did the Soviet Union Collapse?: Understanding Historical Change, New York \& London; M.E. Sharpe.

Suleimenova E. (2011) Yazykovye protsessy i politika [Language Processes and Politics], Alamaty: Kazakh University.

Sultanov B. (ed.) (2011) Kazakhstan: 20 let nezavisimosti [Kazakhstan: 20 Years of Independence], Almaty: Kazakh Institute of Strategic Studies under the President of Kazakhstan.

Suny R. (1993) The Revenge of the Past: Nationalism, Revolution, and the Collapse of the Soviet Union, Stanford: Stanford University Press.

The Law of Ukraine 'On Education' Has Been Aimed at Securing Equal Opportunities for all Ukrainian Citizens in Access to Higher Education (2017). Ministry of Foreign Affairs of Ukraine, September 15, 2017. Available at: https://mfa.gov.ua/news/59779-zakonukrajini-pro-osvitu-spryamovanij-na-zabezpechennya-rivnih-mozhlivostej-dlya-vsihgromadyan-ukrajini-na-zdobuttya-vishhoji-osviti, accessed 20.02.2021 (in Ukrainian).

Tishkov V. (1997) Ethnicity, Nationalism and Conflict in and after the Soviet Union: the Mind Aflame, London: Sage Publications.

Tyshenko K. (2017) Education for Minorities. As It Will Be, Clarifies Liliya Grynevich. Ukrainskaya Pravda, November 8, 2017. Available at: http://life.pravda.com.ua/society/2017/11/8/227339/, accessed 20.02.2021 (in Ukrainian).

Usupova G. (2018) Cultural Nationalism and Everyday Resistance in an Illiberal Nationalising

State: Ethnic Minority Nationalism in Russia. Nations and Nationalism, vol. 4, no 3, pp. 624-647.

Vsesouyuznaya perepis' naseleniya 1989 g. Raspredeleniye naseleniya Ukrainskoy SSR po naibolee mnogochislennym natsionalnostiam $i$ yazyku [The All-Union Population Census. The Distribution of the Ukrainian SSR Population according to the Most Numerous Nationalities and Language] (1989). Available at: http://www.demoscope.ru/weekly/ssp/sng_nac_lan_89_uk.php, accessed 20.02.2021.

Zamyatin K. (2018) Russian-Speaking Nation? The Promotion of the Russian Language and Its Significance for Ongoing Efforts at the Russian Nation-Building. The Politics of Multilingualism: Linguistic Governance, Globalisation and Europeanisation (eds. Grin F., Kraus P.), Amsterdam: John Benjamins, pp. 39-64.

Zevelev I.A. (2008) Sootechestvenniki v Rossiiskoy politike na postsovetskom prostranstve: naslediye imperii i gosudarstvennyi pragmatism [Compatriots in the Russian Policy of the post-Soviet Space: The Heritage of Empire and State Pragmaticism]. Nasledie imperiy $i$ buduschee Rossii [The Heritage of Empires and the Future of Russia] (ed. Miller A.I.), Moscow: Novoye Literaturnoye Obozreniye, pp. 241-293.

Zhakaeva L. (2009) O proportsionalnoy sisteme formirovaniya Medzhlisa parlamenta Kazakhstana [On the Proportional System of Formation of Mazhilis of the Parliament of Kazakhstan]. Konstitutsionnoe i munitsipalnoe pravo, no 7, pp. 27-32.

Zhetpysbaev S. (2017) Etnokul'turnye ob'edinenija v Respublike Kazahstan i ih rol'v konsolidacii grazhdanskogo obshhestva [Ethnocultural Associations in the Republic of Kazakhstan and Their Role in the Consolidation of Civil Society]. Humanitarian Sciences in Siberia, vol. 24, no 1, pp. 86-90. 